\title{
Peluang Pengelolaan Sampah Sebagai Strategi Mitigasi dalam Mewujudkan Ketahanan Iklim Kota Semarang
}

\author{
Wawargita Permata Wijayanti ${ }^{1}$
}

Diterima : 19 Maret 2013

Disetujui : 15 April 2013

\begin{abstract}
This study examined the opportunities in urban waste management as one of the mitigation strategies in reducing $\mathrm{CH}_{4}$ gas emission to strengthen Semarang City's climate resilience. It was perceived as important as Semarang is one of Indonesia's coastal cities vulnerable to the impacts of climate change. It was recognized that the vast amount of waste being dumped at the City Dump was one of the factors contributing to the high emission of $\mathrm{CH}_{4}$ gas in Semarang City. This study employed qualitative approach in identifying and describing the three factors of climate resilience namely: urban system, social agent, and urban institution, accompanied by quantitative scoring approach suggested by IPCC in finding the opportunities of several waste management strategies in building climate resilience. Analysis suggested the followings: (1) waste management at the TPST by third parties at Jatibarang City Dump may lower the emission of $\mathrm{CH}_{4}$ even exceeding the targets set by RAN-PI, (2) urban system being established was categorized as 'sufficient', and (3) social agent and urban institutions were categorized as 'good' to build climate resilience. The strategy of waste management by third parties has more opportunity to contribute in building climate resilience compared to waste management at TPST.
\end{abstract}

Key words: $\mathrm{CH}_{4}$ emission, climate change, mitigation, waste management strategy, climate resilience

\begin{abstract}
ABSTRAK
Penelitian ini mengkaji peluang pengelolaan sampah perkotaan sebagai salah satu strategi mitigasi dalam mengurangi emisi gas $\mathrm{CH}_{4}$ dan menciptakan ketahanan iklim Kota Semarang. Hal ini dipandang penting karena Kota Semarang adalah salah satu kota pesisir yang rentan terhadap dampak perubahan iklim. Sudah dikenal bahwa tingginya timbunan sampah di TPA merupakan salah satu faktor yang berkontribusi terhadap tingginya emisi gas $\mathrm{CH}_{4}$ Kota Semarang. Studi ini menggunakan pendekatan kualitatif untuk mengidentifikasi dan menggambarkan tiga faktor ketahanan iklim, yaitu urban system, social agent, dan urban institution, disertai dengan metode kuantitatif skoring yang disarankan oleh IPCC untuk menemukan peluang beberapa strategi pengelolaan sampah dalam rangka membentuk ketahanan iklim. Analisis menunjukkan: (1) strategi pengolahan sampah di TPST dan oleh pihak ketiga di TPA Jatibarang mampu menurunkan emisi $\mathrm{CH}_{4}$ melampaui target RAN-PI (2) urban system yang dibangun termasuk kategori 'cukup' untuk membentuk ketahanan iklim, dan (3) social agent dan urban institutions berkategori 'baik' untuk membentuk ketahanan iklim. Strategi pengolahan sampah oleh pihak ketiga di TPA memiliki peluang kontribusi lebih besar terhadap pembangunan ketahanan iklim dibandingkan strategi pengolahan sampah di Tempat Pengolahan Sampah Terpadu (TPST).
\end{abstract}

Kata kunci: emisi $\mathrm{CH}_{4}$, perubahan iklim, mitigasi, strategi pengelolaan sampah, ketahanan iklim

\footnotetext{
${ }^{1}$ Alumni Magister Pembangunan Wilayah dan Kota, Universitas Diponegoro
}

Kontak Penulis : wawargita.wijayanti@gmail.com 


\section{PENDAHULUAN}

Perubahan iklim terjadi karena peningkatan konsentrasi gas rumah kaca di atmosfer, sebagai akibat dari transportasi, industri, tumpukan sampah perkotaan, peternakan, pertanian, perubahan tata guna lahan, konversi hutan, dan sebagainya. Gas rumah kaca yang dimaksud adalah $\mathrm{CO}_{2}, \mathrm{CO}, \mathrm{H}_{2} \mathrm{O}, \mathrm{N}_{2}, \mathrm{H}_{2}, \mathrm{OH}, \mathrm{NO}, \mathrm{H}, \mathrm{O}, \mathrm{C}_{\text {dan }} \mathrm{CH}_{4}$. Gas-gas ini terperangkap di atmosfer, menyerap dan memantul kembali. Akibatnya, panas tersimpan di permukaan bumi, terjadi ketidakstabilan dalam lapisan troposfer, dan akhirnya terjadi perubahan iklim. Salah satu gas rumah kaca penyebab perubahan iklim adalah gas metana $\left(\mathrm{CH}_{4}\right)$, yang dihasilkan oleh timbunan sampah. Timbunan sampah yang semakin tinggi di Tempat Pembuangan Akhir tanpa adanya pengolahan lebih lanjut menimbulkan emisi gas metana yang semakin besar. Peningkatan emisi $\mathrm{CH}_{4}$ mengakibatkan dampak perubahan iklim semakin luas. Hal ini disebabkan karena gas metana mempunyai daya rusak 20-30 kali lebih kuat dari $\mathrm{CO}_{2}$. Bahkan, konsentrasi $\mathrm{CH}_{4}$ yang bertahan di atmosfer selama 7-10 tahun dapat meningkatkan suhu bumi sebesar $1,30^{\circ} \mathrm{C}$. Salah satu dampak peningkatan suhu udara adalah meningkatnya proses pencairan es atau gletser di kutub, yang memicu kenaikan volume dan muka air laut. Selain itu, tingginya intensitas curah hujan dan berkurangnya intensitas curah hujan yang ekstrem pada sejumlah wilayah dapat memicu banjir dan kekeringan. Kondisi ini mengakibatkan sejumlah wilayah mengalami kerentanan.

Salah satu kota yang rentan terhadap perubahan iklim adalah Kota Semarang. Kota Semarang terletak di wilayah pesisir sehingga ancaman terhadap kenaikan muka air laut cukup besar. Oleh karena itu, Kota Semarang harus merespon fenomena perubahan iklim sehingga dapat mengurangi dampak yang ditimbulkan dan membawa perkotaan dalam kondisi ketahanan. Ketahanan iklim kota merupakan kondisi ketika suatu kota mampu mengembangkan kapasitas untuk membantu menyerap guncangan perubahan iklim dan menekankan sistem sosial, ekonomi, dan infrastruktur sehingga dapat mempertahankan fungsi dasar, struktur, sistem, dan identitas kota (http://www.resilientcity.org). Ketahanan diperlukan agar Semarang tetap dapat menjalankan fungsi-fungsi perkotaan bagi kesejahteraan penduduk.

Sektor perkotaan yang dapat diintervensi Kota Semarang sebagai respon atas perubahan iklim adalah sektor persampahan. Jika sektor persampahan mampu diintervensi, maka volume gas $\mathrm{CH}_{4}$ pemicu perubahan iklim akan berkurang. Intervensi sektor persampahan penting untuk Kota Semarang karena sistem pengolahan sampah di TPA Jatibarang masih menggunakan controlled landfill, yang masih mengakibatkan tumpukan sampah yang tinggi tanpa proses pengolahan lebih lanjut. Atas dasar inilah, intervensi sektor persampahan perlu dilakukan untuk mengurangi timbunan sampah di TPA sebagai sumber utama penghasil emisi gas $\mathrm{CH}_{4}$. Intervensi sekor persampahan dilakukan dengan melakukan inovasi kegiatan pengolahan sampah sehingga dapat mengurangi timbunan sampah yang berada di TPA Jatibarang, Semarang. Bentuk intervensi terhadap sektor persampahan adalah mengembangkan beberapa strategi pengelolaan sampah sebelum sampah tersebut ditimbun di TPA, yaitu kegiatan pengolahan sampah yang dilakukan pihak ketiga (perusahaan swasta) dan kegiatan pengolahanan sampah skala komunitas di TPST (Tempat Pengolahan Sampah Terpadu).

Inovasi dalam pengolahan sampah tersebut disebut upaya mitigasi terhadap perubaan iklim. Mitigasi terhadap perubahan iklim adalah upaya yang dapat dilakukan untuk mengurangi dampak perubahan iklim dengan cara mencari cara untuk memperlambat atau menahan emisi gas rumah kaca (Klein dan Huq, 2007: 750). Jika pengelolaan sampah dapat dioptimalkan untuk pengurangan emisi $\mathrm{CH}_{4}$ maka dapat mengurangi emisi gas tersebut ke atmosfer. Kondisi tersebut diharapkan mampu memberikan pengaruh pada pengurangan dampak perubahan 
iklim dan menciptakan Kota Semarang yang berketahanan iklim. Untuk mewujudkan ketahanan kota terhadap perubahan iklim, ada beberapa hal yang perlu diperhatikan, yaitu keberhasilan dalam penurunan emisi gas rumah kaca, khususnya $\mathrm{CH}_{4}$, dukungan urban system (infrastruktur perkotaan) dalam tindakan mitigasi, social agent atau stakeholders yang terlibat, serta urban institutions yang mengatur tindakan mitigasi tersebut. Berdasarkan penjelasan di atas, peluang tindakan mitigasi di sektor pengelolaan sampah untuk mewujudkan ketahanan iklim kota menjadi hal yang menarik untuk dilakukannya penelitian.

\section{METODE PENELITIAN}

Penelitian ini bertujuan mengkaji peluang pengelolaan sampah perkotaan sebagai salah satu strategi mitigasi dalam menciptakan ketahanan Kota Semarang terhadap perubahan iklim. Pada penelitian ini, peneliti menggunakan purposive sampling untuk memilih sampel penelitian. Purposive sampling merupakan teknik pemilihan sampel dengan menggunakan kriteria-kriteria tertentu dengan tujuan untuk memperoleh sampel yang dapat dipercaya dan berkapasitas sesuai dengan topik penelitian. Narasumber penelitian ini berjumlah 13 orang, yang terdiri atas Bappeda, Dinas Kebersihan dan Pertamanan, Pihak swasta pengelola sampah Kota Semarang (PT. Narpati), UPTD TPA Jatibarang, dan pengelola Tempat Pengolahan Sampah Terpadu (TPST) Kota Semarang. Pihak-pihak tersebut merupakan aktor kunci yang terlibat dalam kegiatan pengelolaan sampah dan kebijakan perubahan iklim di Kota Semarang. Metode analisis dilakukan dengan cara kualitatif dan kuantitatif. Pada metode kualitatif digunakan teknik kualitatif deskriptif dilakukan untuk untuk mengidentifikasi karakteristik urban system, social agent, dan urban institutions dalam masing-masing strategi pengelolaan sampah. Kemudian, teknik analisis kuantitatif dilakukan untuk menghitung pengurangan emisi gas $\mathrm{CH}_{4}$ dan $\mathrm{CO}_{2}$ dari masing-masing strategi pengelolaan sampah dengan menggunakan rumus IPCC. Selain itu, juga akan dilakukan skoring (penilaian) terhadap karakteristik urban system, social agent, dan urban institutions dalam masing-masing strategi pengelolaan sampah untuk menemukan peluangnya dalam membentuk ketahanan iklim kota.

\section{KAJIAN PENGELOLAAN SAMPAH SEBAGAI STRATEGI MEWUJUDKAN KETAHANAN IKLIM}

\section{Pengelolaan Sampah sebagai Bentuk Mitigasi Perubahan Iklim}

Sampah dapat menghasilkan emisi gas methane $\left(\mathrm{CH}_{4}\right)$. Methane tergolong gas rumah kaca yang berbahaya karena mempunyai pengaruh 21 kali lebih besar dibandingkan gas $\mathrm{CO}_{2}$. Emisi $\mathrm{CH}_{4}$ dari sampah merupakan hasil dekomposisi anaerobik dari materi organik dalam sampah. Sampah terdekomposisi perlahan dan waktu dekomposisi dapat berlangsung dalam waktu yang cukup lama. Kebijakan mitigasi perubahan iklim Indonesia diatur oleh UU No.32 tahun 2009. Melalui UU tersebut mulai diatur arahan penanganan mitigasi terhadap perubahan iklim dan sebagai upaya mendukung pembangunan nasional yang berkelanjutan. Bahkan, Pemerintah Indonesia berkomitmen menurunkan emisi gas rumah kaca sebesar $26 \%$ dengan usaha sendiri dan mencapai $41 \%$ jika mendapat bantuan internasional pada tahun 2020 (Perpres RI No. 61 Tahun 2011).

Salah satu sektor yang dikembangkan dalam mitigasi adalah pengelolaan sampah. Tujuan mitigasi sektor persampahan adalah untuk mengurangi volume sampah perkotaan dan mereduksi emisi gas rumah kaca terutama konsentrasi $\mathrm{CO}_{2}$ dan $\mathrm{CH}_{4}$ sehingga mengurangi pemicu perubahan iklim. Pengembangan mitigasi di sektor persampahan di negara berkembang ditekankan karena pengelolaan sampah di TPA yang masih belum stabil dan 
masih berpotensi menghasilkan emisi gas rumah kaca yang besar sehingga diperlukan penerapan sistem pengelolaan sampah yang dikembangkan dengan strategi pengelolaan limbah alternatif yang disediakan terjangkau dan berkelanjutan (Bogner, et al, 2008: 11). Tujuan mitigasi perubahan iklim di sektor persampahan adalah untuk mengurangi volume dan konsentrasi emisi gas rumah kaca di atmosfer sehingga mampu tercipta kestabilan di atmosfer. IPCC, dalam Avriawan (2011: 3) menyebutkan rumus untuk menghitung emisi gas rumah kaca $\left(\mathrm{CH}_{4}\right)$ adalah:

\section{Methane Emissions (Gg/yr) $=($ MSWT x MSWF x MCF x DOC x DOCF x F x 16/12 - R) x (1- OX)}

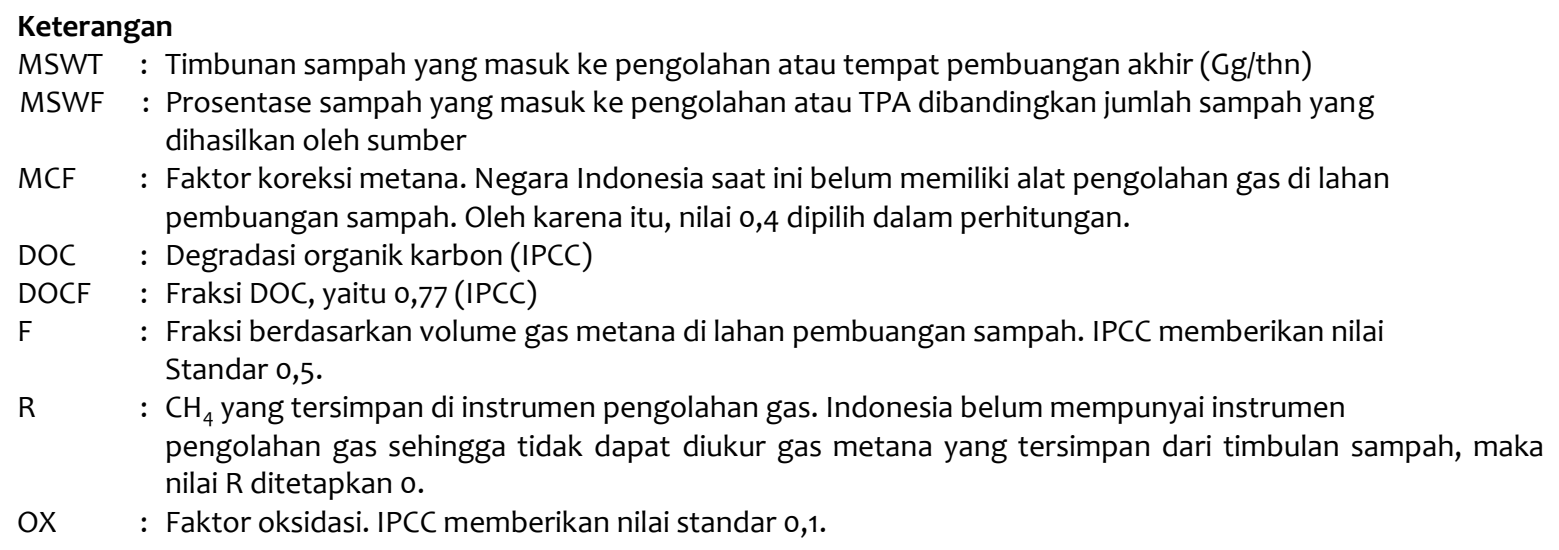

\section{Ketahanan Iklim Kota}

Ketahanan didefinisikan sebagai "kemampuan sistem untuk menyerap guncangan atau ancaman, untuk menghindari dan mengatasi suatu kondisi yang tidak dapat diubah dan tidak memunculkan alternatif, dan untuk melakukan regenerasi setelah gangguan" (http://www.resilientcity.org). Dalam konteks perubahan iklim, gangguan yang dimaksud adalah kondisi yang mengancam dan menimbulkan kerentanan akibat perubahan iklim, misalnya kenaikan muka air laut, suhu dan cuaca yang ekstrem, meningkatnya intensitas curah hujan, penyebaran penyakit tropis, perubahan livelihood masyarakat, dan dampak perubahan iklim yang lain. Dari penjelasan tersebut disimpulkan bahwa ketahanan terhadap perubahan iklim merupakan suatu kondisi dimana suatu sistem dapat mengembalikan kondisi dengan beberapa alternatif kegiatan, berusaha mempertahankan kondisi asli dengan proses, strategi, dan koordinasi yang telah ditentukan, serta berupaya untuk selalu melakukan inovasi dan pembaharuan sehingga suatu sistem dapat bertahanan dari gangguan perubahan iklim.

Ketahanan terhadap perubahan iklim diperlukan untuk mempertahankan sistem dan fungsi perkotaan. Fungsi perkotaan yang dimaksud fungsi kota sebagai pusat pemerintahan, pusat produksi dan konsumsi, pusat perdagangan dan jasa, pusat kebudayaan, dan pusat pertumbuhan penduduk, pusat pelayanan, dan sebagainya. Prasad, et al (2009:32) menyatakan ketahanan kota terhadap iklim tercipta ketika kota mampu menopang dirinya sendiri dan menangani gangguan perubahan iklim yang mengancam, merusak, dan berpotensi merusak. Ketahanan kota dapat terbentuk ketika kota mempunyai daya dukung untuk membangun fungsi perkotaan seperti asli, mengantisipasi gangguan dan ancaman dan merencanakan masa depan (Prasad, et al, 2009:33).

Tyler, et al, 2010 dan Moench, 2011, menyatakan untuk mewujudkan ketahanan iklim ada tiga komponen utama, yaitu urban system, social agents, dan urban institutions. (1) urban system adalah sistem infrastruktur, ekosistem, institusi, dan pengetahuan yang dapat diinterveni 
sebagai bagian dari mitigasi perubahan iklim. (2) social agents didefinisikan sebagai aktor yang terlibat dalam tindakan mitigasi dan pengelolaan sektor perkotaan, baik individu (warga perkotaan), rumah tangga, dan organisasi publik dan privat (lembaga pemerintahan, perusahaan, dan lembaga masyarakat). (3) urban institution ini terkait dengan kerangka kebijakan, hukum, peraturan, dokumen rencana, wewenang, perjanjian, dan sebagainya yang mengatur pelaksanaan strategi mitigasi dan mengatur dan memperjelas hubungan antara urban system dan social agents.

\section{GAMBARAN UMUM LOKASI}

Kebijakan dalam menghadapi perubahan iklim didasarkan pada Perpres RI No. 61 tahun 2011 tentang Rencana Aksi Nasional Perubahan Iklim. Dalam Perpres tersebut disebutkan bahwa Pemerintah Indonesia berkomitmen untuk mengurangi emisi gas rumah kaca sebesar $26 \%$ pada tahun 2020 dan sebesar 41\% jika upaya mitigasi dilakukan dengan bantuan lembaga internasional. Kemudian, Pemerintah Indonesia mengamanatkan bahwa setiap daerah harus menyusun Rencana Aksi Daerah terhadap Perubahan Iklim (RAD-PI). Namun, kebijakan yang mengatur rencana mitigasi belum dimiliki oleh Kota Semarang. Walaupun belum memiliki kebijakan khusus terkait dengan tindakan mitigasi, Kota Semarang mulai menginisiasi tindakan mitigasi pada sektor transportasi, energi, ruang terbuka hijau, persampahan, dan bangunan. Arahan tindakan mitigasi pada masing-masing sektor tersebut tertuang pada kebijakan masingmasing dinas penanggung jawab sektor tersebut. Untuk sektor persampahan menjadi tanggungjawab Dinas Kebersihan dan Bappeda Kota Semarang.

Sektor persampahan merupakan salah satu sektor perkotaan yang dapat diintervensi sebagai bagian dari tindakan mitigasi perubahan iklim. Strategi yang dikembangkan Kota Semarang dalam pengelolaan sampah ini adalah dengan melakukan kegiatan pengolahan sampah oleh pihak swasta di TPA Jatibarang dan kegiatan pengolahan sampah skala rumah tangga di TPST. Target pengurangan emisi dari sektor persampahan di Kota Semarang sebesar 26\% (RAN-PI).

\section{Strategi Pengolahan Sampah oleh Pihak Ketiga di TPA Jatibarang}

Pemerintah Kota Semarang dan Dinas Kebersihan bekerjasama dengan pihak swasta, yaitu PT Narpati Agung Karya Persada Lestari untuk membantu pengolahan sampah di TPA. Pengolahan sampah dilakukan dengan komposting dan pengolahan sampah anorganik. Masa perjanjian kerjasama pengolahan sampah selama 25 tahun, yaitu hingga tahun 2035. Target volume sampah yang akan diolah PT. Narpati hingga tahun 2015 adalah 350 ton/hari. Pada awal operasional tahun 2011, volume sampah yang dapat dikelola hanya 150 ton/hari, kemudian untuk tahun 2012 meningkat menjadi 200 ton/hari. Kemudian, pada tahun 2013, PT. Narpati tetap akan mengolah 200 ton sampah per hari dengan peningkatan jumlah hari kerja.

Produk yang dihasilkan dari kegiatan pengolahan sampah ini antara lain adalah granul (pupuk kompos yang mempunyai butiran-butiran kecil). Selain itu, hasil pengayakan kompos yang kasar dijual ke beberapa lapangan golf di Semarang untuk pemupukan padang golf dan RDF (refused derified fuel) sebagai campuran bahan pembakaran semen. RDF dari PT. Narpati dipesan oleh PT. Semen Gresik. Selain itu, sampah anorganik juga ada yang dijual pada pengepul barang anorganik dan pemulung di sekitar TPA Jatibarang. 

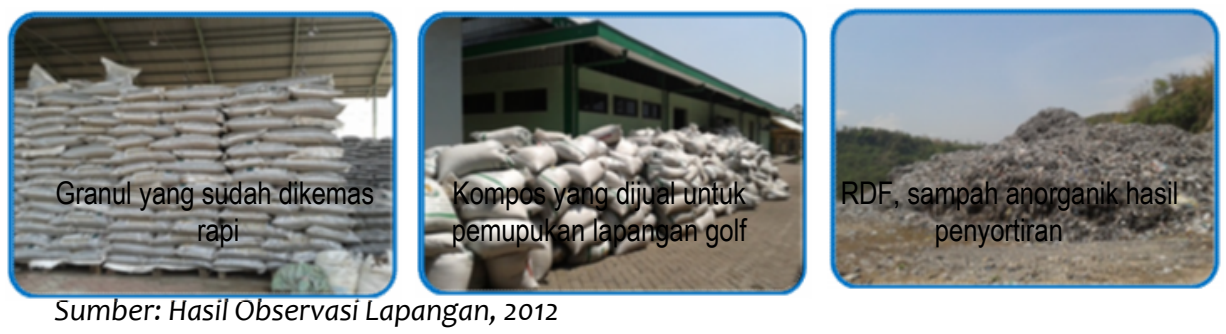

GAMBAR 1

PRODUK HASIL PENGOLAHAN SAMPAH PT. NARPATI

\section{Strategi Pengolahan Sampah di Tempat Pengolahan Sampah Terpadu (TPST)}

Strategi pengelolaan sampah di tingkat sumber ini menggunakan metode $3 R$ (reduce, reuse, dan recycle). Program $3 R$ dilakukan untuk mengurangi sampah dari sumbernya (rumah tangga) dan memperoleh nilai tambah (value added) secara sosial, ekonomi, dan lingkungan. Sarana prasarana yang dibutuhkan dalam kegiatan pengelolaan sampah di tingkat sumber adalah TPST. TPST sebagai wadah pengolahan sampah dengan cara $3 R$, yaitu pemilahan sampah dan pengolahan sampah. Sampah organik digunakan untuk pembuatan kompos, sedangkan sampah anorganik direcycle atau direuse, dan sampah yang benar-benar tidak dapat digunakan langsung diangkut ke TPA. Hingga tahun 2012, jumlah TPST di Kota Semarang adalah 13 unit. Lokasi TPST dapat dilihat pada Gambar 2. Jumlah sampah yang diolah pada masing-masing TPST berbeda-beda, sesuai dengan jumlah penduduk masing-masing lokasi. Rata-rata komposisi sampah yang diolah di TPST adalah $\pm 30 \%$ sampah organik. Sedangkan, untuk sampah anorganik hanya ada 2 TPST yang mengolah, yaitu Sampangan dan Jomblang. Sampah anorganik dari TPST yang lain tetap diangkut dan dibuang ke TPA.

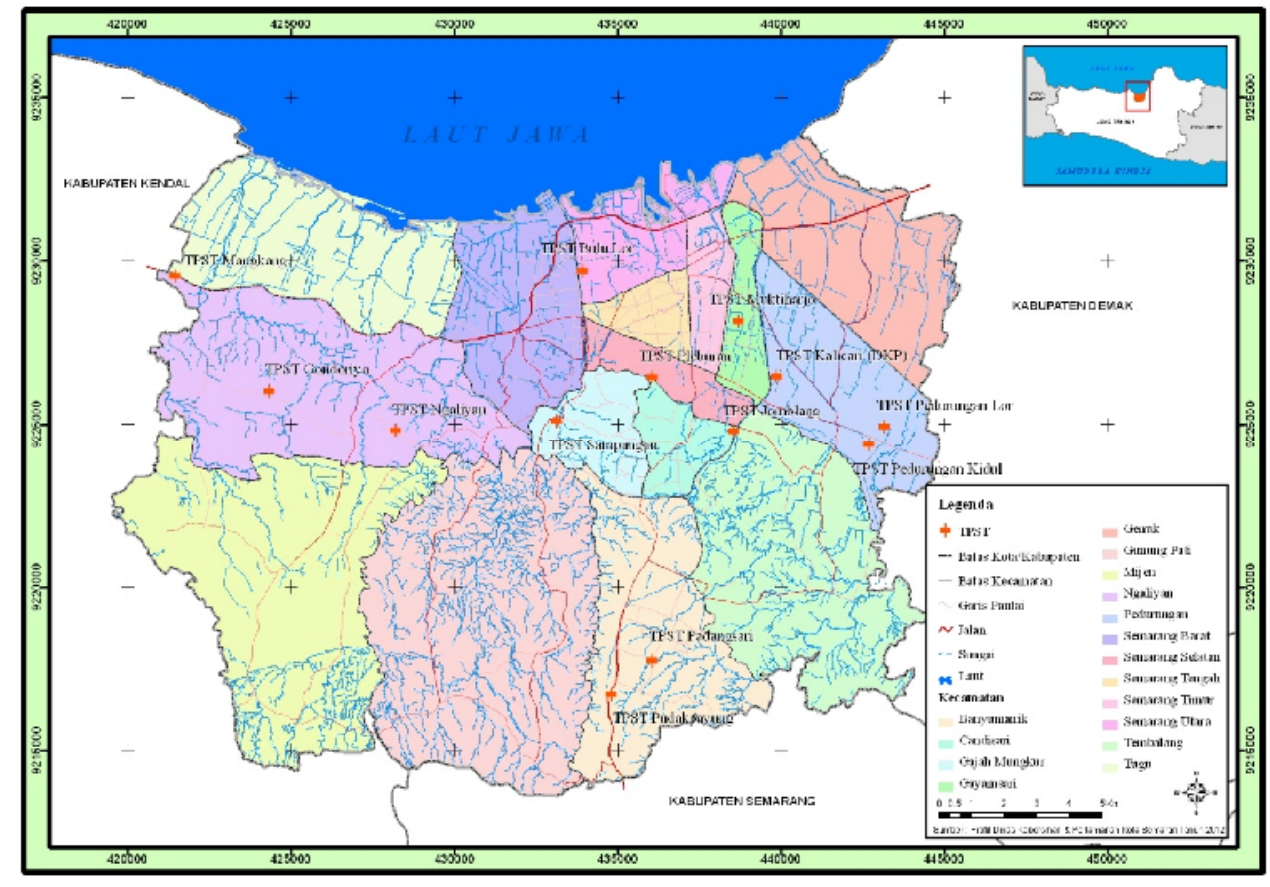

Sumber: Profil Dinas Kebersihan dan Pertamanan, 2012

GAMBAR 2

LOKASI TPST DI KOTA SEMARANG 
Pengelola kegiatan pengolahan sampah tingkat komunitas disebut dengan Kelompok Swadaya Masyarakat (KSM). Keberlangsungan dan kemajuan kegiatan pun bergantung pada kemauan dan keinginan KSM tersebut. Sesuai kondisi tahun 2012, TPST di Kota Semarang dapat dikategorikan menjadi 4 jenis, yaitu kondisi aktif-berkembang, aktif-tidak berkembang, tidak aktif-perbaikan, dan tidak aktif sama sekali. Rincian kondisi masing-masing TPST dapat dilihat pada gambar berikut.

\begin{tabular}{|c|c|}
\hline $\begin{array}{l}\text { TPST AKTIF BERKEMBANG } \\
\text { - TPST Sampangan } \\
\text { - TPST J omblang }\end{array}$ & $\begin{array}{l}\text { TPST TIDAK AKTIF-PERBAIKAN } \\
\text { - TPST Muktiharjo } \\
\text { • TPST Pleburan }\end{array}$ \\
\hline $\begin{array}{l}\text { TPST AKTIF KURANG BERKEMBANG } \\
\text { - TPST Bondho Sepolo } \\
\text { - TPST Pedurungan Kidul } \\
\text { - TPST Pedurungan Lor } \\
\text { - TPST Padangsari } \\
\text { - TPST Ngaliyan } \\
\text { - TPST DKP(Kalicari) }\end{array}$ & $\begin{array}{l}\text { TPST TIDAK AKTIF } \\
\text { • TPST Pudakpayung } \\
\text { - TPST Gondoriyo } \\
\text { • TPST Mangkang }\end{array}$ \\
\hline 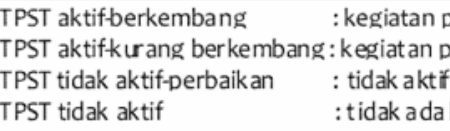 & $\begin{array}{l}\text { osan setiap hari, ada kegia tan daur ulang. } \\
\text { o san sewaktu-waktu, tanpa daur ulang. } \\
\text { etahun kar ena perbaikan TPST. } \\
\text { pengolahan sampah sama sekali. }\end{array}$ \\
\hline
\end{tabular}

GAMBAR 3

KONDISI TPST KOTA SEMARANG TAHUN 2012

\section{ANALISIS STRATEGI PENGELOLAAN SAMPAH DALAM MEMBENTUK KETAHANAN IKLIM KOTA}

\section{Proyeksi Pengurangan Emisi Gas $\mathrm{CH}_{4}$ dan $\mathrm{CO}_{2}$ sebagai Tujuan Mitigasi Perubahan Iklim}

Besarnya nilai $\mathrm{CH}_{4}$ dan $\mathrm{CO}_{2}$ di Kota Semarang akan terus meningkat hingga tahun 2020 seiring dengan semakin tingginya volume sampah yang ditimbun di TPA dan tidak diolah kembali. Perbandingan antara nilai BAU, standar nilai maksimal emisi pada tahun 2020, dan nilai emisi pada kondisi Non-BAU BAU dapat dilihat pada tabel berikut.

TABEL 1

\section{PERBANDINGAN PENURUNAN EMISI GAS CH4 DAN CO2 DI KOTA SEMARANG}

\begin{tabular}{ccccc}
\hline \multirow{3}{*}{$\begin{array}{c}\text { Jenis Gas } \\
\text { Rumah Kaca } \\
\text { dari Sektor } \\
\text { Persampahan }\end{array}$} & $\begin{array}{c}\text { Kondisi BAU } \\
\text { sebagai acuan } \\
\text { pengurangan } \\
\text { emisi }\end{array}$ & $\begin{array}{c}\text { Standar Nilai Emisi } \\
\text { Max Tahun 2020 } \\
\text { (dengan target 26\% } \\
\text { dari kondisi BAU) }\end{array}$ & $\begin{array}{c}\text { Kondisi Non-BAU } \\
\text { (Ada Intervensi } \\
\text { Pengolahan } \\
\text { Sampah) }\end{array}$ & $\begin{array}{c}\text { Persentase } \\
\text { Penurunan Nilai } \\
\text { Emisi Kondisi Non- } \\
\text { BAU (ada } \\
\text { intervensi) }\end{array}$ \\
\hline $\mathrm{CH}_{4}$ & 2,611 & 1,932 & 1,634 & $37,4 \%$ \\
\hline $\mathrm{CO}_{2}$ & 2,886 & 2,135 & 1,909 & $33,8 \%$ \\
\hline
\end{tabular}

Sumber: Hasil Analisis Penyusun, 2013

Keberhasilan pencapaian target penurunan nilai emisi tahun 2020 disebabkan oleh intervensi yang dilakukan, yaitu kegiatan pengoalahan sampah di TPST dengan aktifnya kegiatan pengolahan sampah di 13 unit TPST mulai tahun 2014 dan pembangunan TPST baru sebanyak 10 unit pada tahun 2013-2015. Volume sampah yang diolah di TPST ini meningkat hingga tahun 2020 dengan rata-rata peningkatan $8,73 \%$ per tahun. Selain itu, adanya peningkatan volume 
sampah yang diolah di pihak ketiga (PT. Narpati). volume sampah yang diolah oleh pihak ketiga (PT. Narpati) juga semakin besar, bahkan mencapai $\pm 50 \%$ timbulan sampah Kota Semarang. Ketiga kegiatan tersebut mampu mengurangi volume sampah yang ditimbun di TPA sebesar $20,90 \%$.

Untuk mengetahui strategi pengelolaan sampah yang paling berpeluang dalam membantu keberhasilan pengurangan emisi dapat dilihat dengan volume sampah yang diolah dan peluangnya untuk mengurangi emisi. Pada tahun 2020, volume sampah yang diolah pihak ketiga 17 kali lebih besar dibandingkan volume sampah yang diolah di TPST. Jika dibandingkan dengan volume sampah yang akan diangkut ke TPA, volume sampah yang diolah pihak ketiga sebesar 32,04\%, sedangkan sampah yang diolah di TPST hanya 1,83\%. Kemudian, untuk peluang pengurangan emisi dapat diketahui sebagai berikut.

TABEL 2

PERBANDINGAN NILAI EMISI PER MASING-MASING STRATEGI PENGELOLAAN SAMPAH

\begin{tabular}{ccccccc}
\hline Tahun & $\begin{array}{c}\text { Standar Nilai Emisi } \\
\text { Maksimal Kondisi BAU } \\
\text { (standar 26\%) }\end{array}$ & \multicolumn{2}{c}{$\begin{array}{c}\text { Nilai Emisi jika Pengelolaan } \\
\text { Sampah di TPST dioptimalkan }\end{array}$} & $\begin{array}{c}\text { Nilai Emisi jika Pengelolaan } \\
\text { Sampah di Pihak Ketiga } \\
\text { dioptimalkan }\end{array}$ \\
\cline { 2 - 7 } & $\begin{array}{c}\mathrm{CH}_{4} \\
(\mathrm{Gg} / \text { tahun })\end{array}$ & $\begin{array}{c}\mathrm{CO}_{2} \\
(\mathrm{Gg} / \text { tahun })\end{array}$ & $\begin{array}{c}\mathrm{CH}_{4} \\
(\mathrm{Gg} / \text { tahun })\end{array}$ & $\begin{array}{c}\mathrm{CO}_{2} \\
(\mathrm{Gg} / \text { tahun })\end{array}$ & $\begin{array}{c}\mathrm{CH}_{4} \\
(\mathrm{Gg} / \text { tahun })\end{array}$ & $\begin{array}{c}\mathrm{CO}_{2} \\
(\mathrm{Gg} / \text { tahun })\end{array}$ \\
\hline 2020 & 1,932 & 2,136 & 2,771 & 3,046 & 1,690 & 1,965 \\
\hline Sumber: Hasil Analisis Penyusun, 2013 & & & &
\end{tabular}

\section{Peluang Strategi Pengelolaan Sampah dalam Membentuk Ketahanan Iklim Kota Semarang}

Keberhasilan intervensi pengelolaan sampah di Kota Semarang diharapkan mampu meningkatkan peluang dalam pembentukan ketahanan iklim. Peluang pembentuk ketahanan terlihat dari bagaimana intervensi masing-masing strategi pengelolaan sampah mampu mengurangi emisi gas rumah kaca, dukungan dari urban system, dukungan social agent sebagai pelaksana kegiatan (stakeholders), dan keberadaan urban institutions (kebijakan) yang mengatur tindakan tersebut. Berdasarkan hasil ketiga analisis, maka dilakukan skoring untuk menentukan bagaimana peluang masing-masing strategi dalam membentuk ketahanan, sebagaimana Tabel 3 berikut.

TABEL 3

PENILAIAN PELUANG STRATEGI PENGELOLAAN SAMPAH DI TPST DALAM MEMBENTUK KETAHANAN IKLIM

\begin{tabular}{|c|c|c|c|c|}
\hline Kategori & Kriteria & Penjelasan & Skor & $\begin{array}{l}\text { Total } \\
\text { Skor }\end{array}$ \\
\hline $\begin{array}{l}\text { penuruna } \\
\text { n emisi }\end{array}$ & $\begin{array}{l}\text { penurunan } \\
\text { emisi }\end{array}$ & $\begin{array}{l}\text { pengoptimalan strategi pengelolaan sampah di } \\
\text { TPST belum mampu menurunkan nilai emisi }\end{array}$ & 1 & 1 \\
\hline \multirow{3}{*}{$\begin{array}{l}\text { urban } \\
\text { system }\end{array}$} & flexibility & $\begin{array}{l}\text { pelaksanaan strategi masih dipengaruhi faktor } \\
\text { internal dan eksternal, tetapi kedua strategi } \\
\text { mempunyai upaya antisipasi sehingga kegiatan } \\
\text { dapat berjalan terus menerus }\end{array}$ & 2 & \multirow{3}{*}{7} \\
\hline & diversity & $\begin{array}{l}\text { pelaksanaan strategi pengelolaan sampah TPST } \\
\text { mempunyai keberagaman manfaat, secara internal } \\
\text { dan eksternal }\end{array}$ & 3 & \\
\hline & redudancy & peluang replikasi kegiatan pengelolaan sampah di & 2 & \\
\hline
\end{tabular}




\begin{tabular}{|c|c|c|c|c|}
\hline Kategori & Kriteria & Penjelasan & Skor & $\begin{array}{l}\text { Total } \\
\text { Skor }\end{array}$ \\
\hline & & TPST sangat kecil. & & \\
\hline \multirow{4}{*}{$\begin{array}{l}\text { social } \\
\text { agent dan } \\
\text { urban } \\
\text { institution } \\
\text { S }\end{array}$} & $\begin{array}{l}\text { Responsive } \\
\text { ness }\end{array}$ & $\begin{array}{l}\text { strategi intervensi pengelolaan sampah dapat } \\
\text { berjalan, walaupun rencana tindakan } \\
\text { mitigasi/kebijakan masih dalam tahap penyusunan }\end{array}$ & 3 & \multirow{4}{*}{10} \\
\hline & $\begin{array}{l}\text { Resourcefull } \\
\text { ness }\end{array}$ & $\begin{array}{l}\text { pembiayaan belum mandiri, belum ada } \\
\text { pemanfataan peluang baru dari kegiatan } \\
\text { pengelolaan sampah, dan hanya sebagian pihak } \\
\text { yang bekerja sama dengan pihak lain }\end{array}$ & 2 & \\
\hline & $\begin{array}{l}\text { capacity to } \\
\text { learn }\end{array}$ & $\begin{array}{l}\text { ada rencana untuk pengoptimalan kegiatan } \\
\text { pengelolaan sampah di TPST dan inovasi kegiatan } \\
\text { (penghijauan) }\end{array}$ & 3 & \\
\hline & $\begin{array}{l}\text { urban } \\
\text { institutions }\end{array}$ & $\begin{array}{l}\text { belum adanya urban institutions khusus yang } \\
\text { mengatur mitigasi perubahan iklim, tetapi telah ada } \\
\text { upaya untuk menyusun kebijakan terkait. }\end{array}$ & 2 & \\
\hline & & Total & & 18 \\
\hline
\end{tabular}

Sumber: Hasil Analisis Penyusun, 2013

TABEL 4

PENILAIAN PELUANG STRATEGI PENGELOLAAN SAMPAH DI PIHAK KETIGA (PT. NARPATI) DALAM MEMBENTUK KETAHANAN IKLIM

\begin{tabular}{|c|c|c|c|c|}
\hline Kategori & Kriteria & Penjelasan & Skor & $\begin{array}{l}\text { Total } \\
\text { Skor }\end{array}$ \\
\hline $\begin{array}{l}\text { penurunan } \\
\text { emisi }\end{array}$ & $\begin{array}{l}\text { penurunan } \\
\text { emisi }\end{array}$ & $\begin{array}{l}\text { pengoptimalan strategi pengelolaan sampah di TPST } \\
\text { belum mampu menurunkan emisi }>26 \% \text {. }\end{array}$ & 3 & 3 \\
\hline \multirow{3}{*}{$\begin{array}{l}\text { urban } \\
\text { system }\end{array}$} & flexibility & $\begin{array}{l}\text { pelaksanaan strategi masih dipengaruhi faktor } \\
\text { internal dan eksternal, tetapi kedua strategi } \\
\text { mempunyai upaya antisipasi sehingga kegiatan dapat } \\
\text { berjalan terus menerus }\end{array}$ & 2 & \multirow{3}{*}{6} \\
\hline & diversity & $\begin{array}{l}\text { pelaksanaan strategi pengelolaan sampah } \\
\text { mempunyai keberagaman manfaat, secara internal } \\
\text { dan eksternal }\end{array}$ & 3 & \\
\hline & redudancy & $\begin{array}{l}\text { replikasi sulit untuk dilakukan karena keterbatasan } \\
\text { lahan, kendala teknis, dan non-teknis. }\end{array}$ & 1 & \\
\hline \multirow{4}{*}{$\begin{array}{l}\text { social agent } \\
\text { dan urban } \\
\text { institution }\end{array}$} & $\begin{array}{l}\text { Responsive } \\
\text { ness }\end{array}$ & $\begin{array}{l}\text { strategi intervensi pengelolaan sampah dapat } \\
\text { berjalan, walaupun rencana tindakan } \\
\text { mitigasi/kebijakan masih dalam tahap penyusunan }\end{array}$ & 3 & \multirow{4}{*}{10} \\
\hline & $\begin{array}{l}\text { resourcefull } \\
\text { ness }\end{array}$ & $\begin{array}{l}\text { pembiayaan mandiri, ada usaha untuk pemanfataan } \\
\text { peluang baru dari kegiatan pengelolaan sampah, dan } \\
\text { pihak pengelola sampah mampu bekerja sama } \\
\text { dengan pihak lain }\end{array}$ & 3 & \\
\hline & $\begin{array}{l}\text { capacity to } \\
\text { learn }\end{array}$ & $\begin{array}{l}\text { ada rencana inovasi kegiatan serupa, yaitu ITF, tetapi } \\
\text { pelaksanaan masih terhambat kendala teknis dan } \\
\text { non-teknis }\end{array}$ & 2 & \\
\hline & $\begin{array}{l}\text { urban } \\
\text { institutions }\end{array}$ & $\begin{array}{l}\text { belum adanya urban institutions khusus yang } \\
\text { mengatur mitigasi perubahan iklim, tetapi telah ada }\end{array}$ & 2 & \\
\hline
\end{tabular}




\begin{tabular}{|c|c|c|c|c|}
\hline Kategori & Kriteria & Penjelasan & Skor & $\begin{array}{l}\text { Total } \\
\text { Skor }\end{array}$ \\
\hline \multicolumn{5}{|c|}{ upaya untuk menyusun kebijakan terkait. } \\
\hline & & & & 19 \\
\hline
\end{tabular}

Sumber: Hasil Analisis Penyusun, 2013

Berdasarkan penilaian di atas terlihat bahwa kedua strategi pengelolaan sampah berpeluang dan mampu membantu pembentukan ketahanan iklim. Namun, strategi yang mempunyai peluang lebih besar adalah strategi pengelolaan sampah di pihak ketiga (PT. Narpati), yang ditunjukkan dengan total skor 19, termasuk kategori berpeluang baik dalam membentuk ketahanan iklim. Lain halnya dengan strategi pengelolaan sampah di TPST, yang mempunyai total skor lebih kecil, yaitu 18, termasuk dalam kategori cukup dalam membentuk ketahanan iklim.

Pada kedua strategi pengelolaan sampah terlihat ada perbedaan kriteria dalam keberhasilan kedua strategi pengelolaan sampah untuk membentuk ketahanan iklim. Perbedaan tersebut dapat ditunjukkan dengan tabel berikut.

TABEL 5

KEBERHASILAN MASING-MASING STRATEGI PENGELOLAAN SAMPAH DALAM MEMBENTUK KETAHANAN IKLIM

\begin{tabular}{llll}
\hline \multicolumn{1}{c}{ Strategi Pengelolaan Sampah di TPST } & \multicolumn{2}{l}{ Strategi Pengelolaan Sampah di pihak ketiga (PT. } \\
Narpati)
\end{tabular}

\section{KESIMPULAN}

Intervensi Kota Semarang terhadap sektor persampahan dilakukan dengan pengolahan sampah di Tempat Pengolahan Sampah Terpadu (TPST) mulai tahun 2008 dan kegiatan pengolahan sampah oleh pihak ketiga di TPA Jatibarang mulai tahun 2011. Adanya intervensi tersebut mengurangi volume sampah yang ditimbun di TPA sebesar 20,90\%. Dengan berkurangnya volume sampah yang ditimbun di TPA, maka nilai emisi gas $\mathrm{CH}_{4}$ dan $\mathrm{CO}_{2}$ adalah $1,634 \mathrm{Gg} /$ tahun untuk $\mathrm{CH}_{4}$ dan $1,909 \mathrm{Gg} /$ tahun untuk $\mathrm{CO}_{2}$, artinya nilai emisi gas $\mathrm{CH}_{4}$ dan $\mathrm{CO}_{2}$ berhasil diturunkan sebesar $37,4 \% \mathrm{CH}_{4}$ dan $33,8 \% \mathrm{CO}_{2}$. Jika dilihat per masing-masing strategi pengelolaan sampah, strategi pengelolaan sampah di pihak ketiga (PT. Narpati) mampu menurunkan nilai emisi Kota Semarang sebesar 35,27\% untuk $\mathrm{CH}_{4}$ dan 31,91\% untuk $\mathrm{CO}_{2}$, sedangkan pada strategi pengelolaan sampah di TPST belum mampu menurunkan nilai emisi kedua gas tersebut. 
Intervensi sektor persampahan diharapkan turut berkontribusi dalam pembentukan ketahanan iklim kota. Sesuai dengan kondisi saat ini, intervensi sektor persampahan berpeluang dalam membentuk ketahanan iklim kota. Hal tersebut didasarkan pada keberhasilan kedua strategi pengelolaan sampah. Namun, strategi yang lebih berpeluang dalam membantu pembentukan ketahanan iklim di Kota Semarang adalah strategi pengelolaan sampah oleh pihak ketiga (PT. Narpati).

Untuk jangka panjang, faktor-faktor pembentuk ketahanan masih berpeluang untuk dapat dioptimalkan guna mempermudah proses mewujudkan ketahanan. Kriteria-kriteria yang masih harus dioptimalkan antara lain flexibility, redudancy, capacity to learn pada strategi pengelolaan sampah oleh pihak ketiga dan kriteria flexibility, resourcefullness, dan penurunan emisi gas rumah kaca pada strategi pengelolaan sampah di TPST. Jika semua kriteria pada masingmasing strategi pengelolaan sampah mampu dioptimalkan dan dimanfaatkan dengan baik, maka ketahanan iklim Kota Semarang lebih cepat terwujud di Kota Semarang.

\section{DAFTAR PUSTAKA}

Avriawan, Widyananda dan Susi Agustina Wilujeng. 2011. Studi Emisi Karbondioksida (CO2) dan Metana ( $\left.\mathrm{CH}_{4}\right)$ dari Kegiatan Reduksi Sampah di Wilayah Surabaya Bagian Utara. Skripsi Jurusan Teknik Lingkungan Fakultas Teknik Sipil dan Perencanaan ITS Surabaya.

Bogner, Jean, et al. 2008. "Mitigation of Global Greenhouse Gas Emissions from Waste: Conclusions and Strategies from The Intergovernmental Panel on Climate Change (IPCC) Fourth Assessment Report. Working Group III (Mitigation)." Waste Management and Research, Vol. 26, pp.11-32.

Klein, Richard, J.T. dan Saleemul Huq. 2007. Inter-Relationships Between Adaptation and Mitigation. Fourth Assessment Report (AR4): Contribution of Working Group II to the Fourth Assessment Report of the Intergovernmental Panel on Climate Change. Cambridge, UK: Cambridge University Press.

Moench, Marcus, Stephen Tyler, and Jessica Lage. 2011. Catalyzing Urban Climate Resilience. Boulder, CO, USA: Institute for Social and Environmental Transition International.

Peraturan Presiden Republik Indonesia No. 61 Tahun 2011 tentang Rencana Aksi Nasional Perubahan Iklim.

Profil Dinas Kebersihan dan Pertamanan Kota Semarang. 2012.

Prasad, Neeraj, Federica Ranghieri, Fatima Shah, Zoe Trohanis, Earl Kessler, Ravi Sinha, et al. 2009. Climate Resilient City: A Primer on Reducing Vulnerabilities to Disasters. Washington DC: World Bank.

Resilience City Organisation. Tanpa angkta tahun. Resilience City. Available at http://www.resilientcity.org/index.cfm?PAGEPATH=Resilience\&ID=114. Diakses pada tanggal 2 Juli 2012.

Tyler, Stephen, Sarah Orleans Reed, Karenmacclune, dan Shashikant Chopde. 2010. Planning for Urban Climate Resilience: Framework and Examples from the Asian Cities Climate Change Resilience Network (ACCCRN). Colorado: Asian Cities Climate Change Resilience Network (ACCCRN). 